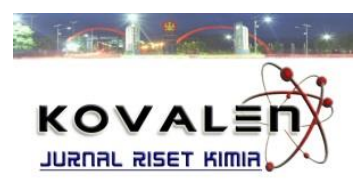

\title{
APLIKASI SELULOSA BAKTERIAL-DIETILENTRIAMINA SEBAGAI LAPISAN PENGIKAT LOGAM Pb DAN Cd PADA METODE DIFFUSIVE GRADIENT IN THIN FILMS (DGT)
}

\section{[Application of Bacterial Cellulose-Diethylenetriamine as Binding Layer of Metal Pb and Cd in Diffusive Gradient in Thin Films (DGT) Method]}

\author{
Khairuddin $^{{ }^{*}}{ }^{\star}$, Prismawiryanti $^{1}$, Indriani ${ }^{1}$ \\ 1) Jurusan Kimia FMIPA Universitas Tadulako \\ Jl. Soekarno Hatta, Kampus Bumi Tadulako Tondo Palu, Telp. 0451- 422611
}

Diterima 2 Februari 2017, Disetujui 6 Maret 2017

\begin{abstract}
This research aimed to synthesis and apply of bacterial cellulose-diethylenetriamine as a binding layer on the diffusive gradients in thin films method for preconcentration of labile metal $\mathrm{Pb}$ and $\mathrm{Cd}$ in aquatic systems and sediment of Palu Bay. The results are expected to be used for the analysis of environmental contaminants aquatic pollutant/sediment replace conventional methods. DGT method easily carried into the field and sensitive to identify certain metal ions. The results showed concentration of heavy metals dissolved in seawater for $\mathrm{Pb}$ between 0.024 to $0.048 \mathrm{mg} / \mathrm{L}$, while for Cd between 0.006 to $0.015 \mathrm{mg} / \mathrm{L}$. The concentration of Pb in sediments from 7.426 to $16.043 \mathrm{mg} / \mathrm{L}$ and $\mathrm{Cd} 0.387$ to $0.950 \mathrm{mg} / \mathrm{L}$. Partial regression analysis between $\mathrm{Pb}$ and Cd concentrations in water with a concentration of cadmium metals $\mathrm{Pb}$ and $\mathrm{Cd}$ in the sediments showed that the concentration of heavy metals in water has a positive correlation with the concentration of $\mathrm{Pb}$ and $\mathrm{Cd}$ in the sediment.
\end{abstract}

Keyword: $P b, C d, D G T$, bacterial cellulose-diethylenetriamine, Palu Bay

\begin{abstract}
ABSTRAK
Tujuan penelitian adalah membuat dan mengaplikasikan selulosa bakterial yang dimodifikasi dengan senyawa dietilentriamina sebagai lapisan pengikat logam dalam sistem perairan pada perangkat prototipe Diffusive Gradient in Thin Film (DGT) untuk kajian logam labil timbal ( $\mathrm{Pb}$ ) dan kadmium (Cd) pada air laut dan sedimen Teluk Palu. Metode DGT ini dapat digunakan untuk memonitor kualitas lingkungan perairan/sedimen secara in situ. Hasil penelitian diharapkan dapat digunakan untuk analisis polutan pencemar lingkungan perairan/sedimen menggantikan metode konvensional. Suatu kelebihan dari metoda DGT ini karena mudah dibawa ke lapangan dan sensitif untuk mengidentifikasi ion logam tertentu. Pengamatan saat penelitian terhadap kualitas perairan pada lokasi sampling di Perairan Teluk Palu dari parameter temperatur, salinitas, dan $\mathrm{pH}$, masih dapat dikatakan berada pada kondisi normal pada saat pengukuran. Konsentrasi logam berat terlarut dalam air laut untuk $\mathrm{Pb}$ antara $0,024-0,048$ $\mathrm{mg} / \mathrm{L}$, sedangkan untuk $\mathrm{Cd}$ antara 0,006-0,015 mg/L. Konsentrasi $\mathrm{Pb}$ dalam sedimen 7,426 - 16,043 $\mathrm{mg} / \mathrm{L}$ dan $\mathrm{Cd}$ 0,387-0,950 mg/L. Hasil analisis regresi parsial antara konsentrasi logam $\mathrm{Pb}$ dan $\mathrm{Cd}$ dalam air dengan konsentrasi logam kadmium $\mathrm{Pb}$ dan $\mathrm{Cd}$ dalam sedimen menunjukkan bahwa antara konsentrasi logam berat tersebut dalam air memiliki korelasi yang positif dengan konsentrasi logam $\mathrm{Pb}$ dan Cd dalam sedimen.
\end{abstract}

Kata kunci: Logam Pb, Logam Cd, DGT, selulosa bakterial-dietilentriamina, Teluk Palu. 


\section{LATAR BELAKANG}

Kawasan pemukiman penduduk yang semakin meluas dan semakin berkembangnya kawasan industri di kota besar tidak lain diakibatkan oleh jumlah penduduk yang terus meningkat. Peristiwa tersebut menjadi pemicu terjadinya peningkatan pencemaran logam berat pada perairan sungai dan laut, dikarenakan semua limbah dari daratan, baik yang berasal dari pemukiman perkotaan maupun dari kawasan industry dan pada akhirnya bermuara ke sungai dan laut.

Unsur-unsur runut (trace elements) di dalam air sungai maupun air laut terdapat dalam berbagai bentuk kimia atau spesi, berbagai bentuk ini dapat berupa koloid, kompleks anorganik, kompleks dengan bahan organik terlarut (dissolved organic matter), dan ion-ion bebas. Masing-masing spesi tersebut berbeda dalam hal toksisitas dan bioavailability. Toksisitas dan bioavailability spesi ion $\mathrm{Pb}$ dan $\mathrm{Cd}$, seng, kadmium $\left(\mathrm{Zn}^{2+}, \mathrm{Cu}^{2+}, \mathrm{Cd}^{2+}\right)$ terhadap organisme air jauh lebih tinggi dibandingkan jika unsur-unsur tersebut membentuk kompleks dengan bahan organik terlarut, koloid ataupun partikel lainnya. Tetapi hal tersebut di atas tidak seluruhnya berlaku terhadap unsur runut logam lainnya. Sebagai contoh pada logam merkuri dan timbal, jika terjadi proses metilasi maka toksisitas kedua kompleks ini akan jauh lebih tinggi bila dibandingkan dalam keadaan ion bebas.
Logam berat juga dapat terakumulasi baik dalam sedimen laut maupun biota laut melalui proses bioakumulasi, gravitasi, biomagnifikasi, dan biokonsentrasi oleh biota laut (Chethan et al., 2015).

Kadar logam berat dalam air yang terus meningkat akan diikuti oleh peningkatan kadar logam berat tersebut dalam tubuh biota, yang tentunya diakhiri dengan timbulnya pencemaran. Variasi spesi logam telah diidentifikasi pada perairan alami termasuk bentuk spesi organik dan anorganik dan sangat tergantung pada konsentrasi logam, kekuatan ion maupun $\mathrm{pH}$. Timbal merupakan jenis logam yang kerap dijumpai pada sistem perairan dan dapat dalam bentuk ion bebas dan juga dalam bentuk kompleks dengan bahan organik terlarut. Logam ini akan menjadi beracun pada tingkatan 10 - 50 dari konsentrasi normal yang dibutuhkan pada proses pertumbuhan organisme dan biota air, sehingga perlu dilakukan monitoring (Shaaban et al., 2014, dan Ahmad et al., 2012).

Pencemaran di perairan akibat logam berat tidak dapat dibiarkan terus berlangsung, karena dapat memberikan dampak yang sangat buruk terhadap kelangsungan hidup biota laut dan makhluk hidup sekitarnya. Oleh karena itu, diperlukan pemantuan khusus dan sering dilakukan pengukuran kadar logam berat di lingkungan, khususnya pada lingkungan perairan walaupun pengukuran logam 
runut dalam sistem perairan relatif sulit untuk dilakukan.

Metode sampling menggunakan metode gradien difusi dalam film tipis (Diffusive Gradient in Thin Films) adalah pendekatan baru untuk pendugaan pencemaran logam berat dan status ekotoksikologi lingkungan perairan (Scally et al., 2006, Dahlqvist et al., 2002). Bill Davison dan Hao Zhang pertama kali mengembangkan metode ini dari tahun 1993 di Lancaster, Inggris dan kemudian dipatenkan oleh Lancaster University. Teknik ini adalah teknik prekonsentrasi insitu dan merupakan teknik passive sampling yang sesuai untuk mengukur spesi labil yang terakumulasi di lingkungan akuatik. DGT terdiri dari alat sederhana yang terbuat dari plastik berbentuk bulat dengan diameter $2,5 \mathrm{~cm}$. Alat ini diisi dengan lapisan pengkelat logam dan membran filter $0,45 \mu \mathrm{m}$ serta hidrogel sebagai lapisan difusi. Hidrogel poliakrilamida adalah jaringan polimer tiga dimensi yang bersifat hidrofilik, tetapi tidak larut dalam air. Saat hidrogel terhidrasi, maka sekitar 95\% air dapat berdisfusi masuk ke dalam hidrogel. Hidrogel memiliki sifat menarik lainnya, yaitu kemampuannya untuk berinteraksi dengan spesies kimia (misalnya $\mathrm{Cd}, \mathrm{Pb}, \mathrm{Cr}, \mathrm{Hg}$ ) melalui gugus-gugus polar yang bertanggung jawab untuk sifat hidrofilik, kapasitasnya untuk memungkinkan difusi yang terkendali, respon pembengkakan (swelling) terhadap perubahan konsentrasi ion, pH, dan suhu (Shaaban et al., 2014).
Logam berat dalam air laut terdapat dalam bentuk logam terlarut dan tersuspensi. Kedua bentuk ini dapat dipisahkan melalui penyaringan dengan menggunakan membran filter yang berukuran pori $0,45 \mu \mathrm{m}$. Ion berdifusi melalui filter membran dengan cara pembentukan gradien konsentrasi yang konstan sehingga terkumpul pada lapisan pengkelat (binding layer) yang menjadi dasar untuk mengukur logam dalam larutan secara kuantitatif. Massa logam pada lapisan pengkelat diukur setelah dielusi dengan larutan asam (Dunn et al., 2007). Konsentrasi spesi analit yang diikat lapisan pengkelat logam DGT dianggap sama dengan konsentrasi yang berdifusi ke biota akuatik sehingga metode ini juga dapat memprediksi bioavailabilitas spesispesi anorganik labil seperti logam, fosfat, dan sulfida.

DGT terdiri dari tiga lapisan, diantaranya gel lapisan pengkelat logam, gel lapisan difusi, dan filter membran. Filter membran digunakan untuk memisahkan partikel tersuspensi pada peristiwa difusi. Ion logam labil dalam larutan akan berdifusi melalui filter membran dan lapisan difusi hingga akhirnya diprekonsentrasi pada gel pengkelat logam (Mojsilovic et al., 2011, Czaja et al., 2004).

Analit berdifusi dari larutan sampel melalui lapisan difusi kemudian diprekonsentrasi pada lapisan pengikat. Dengan demikian gradien konsentrasi pada lapisan difusi hingga konsentrasinya 
sama dengan konsentrasi pada larutan sampel. Massa logam dikumpulkan oleh gel selulosa bakterial-dietilentriamina dari larutan logam menurut Persamaan (1).

$$
\mathrm{C}=\frac{M \cdot \Delta g}{D . t \cdot A}
$$

di mana $C$ adalah konsentrasi logam dalam bulk solusi, M massa logam dalam gel selulosa bakterial-dietilentriamina, $\Delta \mathrm{g}$ ketebalan lapisan difusi, D koefisien difusi ion logam dalam lapisan difusi, $t$ waktu kontak dan $A$ luas permukaan kontak.

Massa logam dikumpulkan oleh selulosa bakterial-dietilentriamina dihitung setelah elusi gel selulosa bakterialdietilentriamina dalam $\mathrm{HNO}_{3} 1 \mathrm{M}$ menurut persamaan ( 2 ).

$$
\mathrm{M}=\frac{C_{e}\left(V_{g}+V_{e}\right)}{f_{e}}
$$

dimana $C_{e}$ adalah konsentrasi logam dalam eluen, $V_{g}$ dan $V_{e}$ masing-masing volume gel selulosa bakterialdietilentriamina dan eluen, dan $f_{e}$ adalah faktor elusi (Shaaban et al., 2014).

Dalam penelitian ini dibuat modifikasi selulosa bakterialdietilentriamina sebagai bahan lapisan pengikat logam untuk diaplikasikan pada metode gradien difusi dalam film tipis dalam pengukuran $\mathrm{Pb}$ baik dalam larutan maupun pada sampel air dan sedimen dari perairan laut Teluk Palu.

\section{METODE PENELITIAN}

\section{Bahan dan Peralatan}

Bahan yang digunakan, yaitu selulosa bakterial, Akrilamida, Air bebas mineral, Bis-akrilamida, Amonium persulfat $\quad\left(\mathrm{NH}_{4} \mathrm{~S}_{2} \mathrm{O}_{8}\right), \quad \mathrm{N}, \mathrm{N}, \mathrm{N}^{\prime} \mathrm{N}^{\prime}-$

Tetrametiletilendiamina

(TEMED), membran selulosa nitrat $0,45 \mu \mathrm{m}, \mathrm{NaNO}_{3}$, $\mathrm{NaOH}, \mathrm{HNO}_{3}$.

Peralatan penelitian meliputi probe DGT (DGT Research - Lancaster University, Inggris), FTIR, Spektrofotometer Serapan Atom, $\mathrm{pH}$ meter, timbangan analitik.

\section{Prosedur Penelitian}

\section{Sintesis lapisan Pengkelat Logam Dietilentriamina-Selulosa Bakterial}

Serbuk selulosa direndam dalam larutan $\mathrm{NaOH} 15 \%$ selama satu jam pada temperatur kamar yang dilanjutkan dengan pencucian dengan air mengalir. Selulosa sebanyak 1 gram lalu diletakkan dalam gelas kimia dengan magnetik stirrer dan ditambahkan epiklororohidrin sebanyak $3 \mathrm{~mL}$ dan $100 \mathrm{~mL}$ larutan $\mathrm{NaOH}$ 8\%. Reaksi dilakukan selama 10 jam sambil diaduk dengan magnetik stirrer. Produk hasil reaksi dicuci dengan air bebas mineral dan etanol anhidrat hingga $\mathrm{pH}$ 7,0 lalu dikeringkan pada temperatur $60^{\circ} \mathrm{C}$. Produk hasil reaksi sebanyak 1 gram dicampurkan dengan 1 gram dietilentriamina dan $100 \mathrm{~mL}$ air bebas mineral dan $\mathrm{NaHCO}_{3}$ sebagai katalis sambil terus diaduk pada temperatur $50^{\circ} \mathrm{C}$ selama 2 jam. Produk yang dihasilkan dicuci dengan air dan etanol anhidrat hingga $\mathrm{pH} 7,0$ dan selanjutnya dikeringkan pada temperatur $60^{\circ} \mathrm{C}$.

\section{Karakterisasi Gugus Fungsi}

Selulosa dan selulosa teraminasi 
dietilentriamina dikarakterisasi pada bilangan gelombang $450 \mathrm{~cm}^{-1}$ sampai dengan $4000 \mathrm{~cm}^{-1}$ dengan spektrofotometer FTIR. Penyiapan cuplikan dilakukan dengan metode pellet $\mathrm{KBr}$.

\section{Pembuatan Gel Difusi}

Pembuatan gel poliakrilamida sebagai gel difusi ion mengikuti prosedur yang digunakan oleh Jennifer Morford et al. (2003). Campuran gel monomer akrilamida $(6 \%)$ dan cross linker bisakrilamida $(0,8 \%)$ direaksikan dengan tetrametiletilenadiamina (TEMED), dan katalis amonium persulfat (10\% larutan) untuk membuat gel poliakrilamida. Larutan gel disiapkan melalui pencampuran akrilamida dan cross-linker bis akrilamida. Polimerisasi dimulai dengan menambahkan $6 \mu \mathrm{L}$ amonium persulfat dan $2,5 \mu \mathrm{L}$ tetrametiletilendiamina (TEMED) per mililiter larutan gel. Larutan gel yang dihasilkan lalu diletakkan pada cetakan kaca $0,78 \mathrm{~mm}$. Setelah dikeluarkan, gel dihidrasi untuk membuat gel menjadi stabil. Gel kemudian dicetak dengan diameter $2,5 \mathrm{~cm}$.

\section{Pembuatan Gel Dietilentriamina- Selulosa Bakterial.}

Sebanyak 0,2 g dietilentriaminaselulosa bakterial (100 mesh) ditambahkan permililiter larutan gel difusi. Polimerisasi gel melalui penambahan $6 \mu \mathrm{L}$ amonium persulfat dan $2 \mu \mathrm{L}$ TEMED permililiter larutan gel difusi untuk pembentukan gel dietilentriamina-selulosa bakterial. Gel kemudian dicetak dengan diameter 2,5 cm kemudian disimpan dalam 0,01 $\mathrm{M} \mathrm{NaNO}_{3}$ hingga akan digunakan.

\section{Pemasangan Perangkat DGT}

Untuk mengaplikasikan DGT, hal pertama yang dilakukan adalah menyiapkan unit DGT yaitu dengan cara meletakkan gel pengkelat logam dietilentriamina-selulosa bakterial, gel difusi poliakrilamida, serta membran selulosa nitrat secara berurutan seperti terlihat pada Gambar 1.

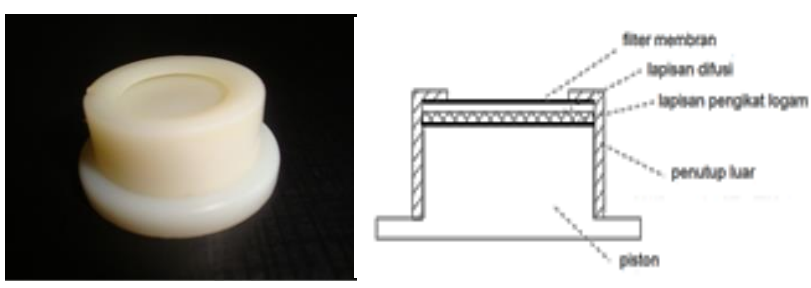

Gambar 1 Susunan filter membran 0,45 $\mu \mathrm{m}$, gel lapisan difusi, dan lapisan pengkelat logam dalam probe DGT

\section{Pengambilan Sampel Sedimen}

Sampel sedimen diperoleh dengan menggunakan potongan pipa paralon atau corer sampel yang ditancapkan ke dalam sedimen pada beberapa titik sampel dikawasan perairan estuaria Teluk Palu. Sampel yang diperoleh dimasukkan dalam botol plastik dan ditutup rapat.

\section{Aplikasi DGT pada Sampel Sedimen Laut}

Sejumlah sampel sedimen dimasukkan dalam pot. Rancangan sampler DGT untuk sedimen dimasukkan ke dalam sedimen selama $3 \times 24$ jam. Lapisan pengikat logam dari sampler kemudian dipisahkan dan dielusi dengan 
$10 \mathrm{~mL}$ HNO3 $1 \mathrm{M}$ selama 24 jam. Kadar logam dalam larutan hasil elusi dianalisis dengan AAS.

\section{Aplikasi DGT pada Sampel Air Laut}

Membran filter selulosa $0,45 \mu \mathrm{m}$ dibasahi dengan air bebas ion, kemudian diatur membran gel dan penyaring pada dasar perangkat DGT. Lapisan pengikat logam kemudian ditempatkan gel difusi diikuti oleh membran filter. Tutup ditekan erat dalam posisi horizontal.

Air laut disampling dari empat titik di perairan Teluk Palu. Sampel air lalu ditempatkan pada beaker glass $1000 \mathrm{~mL}$. Perangkat DGT yang telah disusun sesuai urutannya, dimasukkan pada air laut yang akan diuji. Setelah itu lapisan pengikat (binding layer) dielusi dalam $2 \mathrm{~mL}$ larutan $\mathrm{HNO}_{3} 1 \mathrm{M}$ selama 24 jam. Larutan hasil elusi diukur dengan menggunakan AAS sehingga dapat diketahui konsentrasi $\mathrm{Pb}^{2+}$ dan $\mathrm{Cd}^{2+}$.

\section{HASIL DAN PEMBAHASAN}

Pada sintesis dietilentriamina selulosa bakterial, gugus hidroksil selulosa bakterial bereaksi dengan epiklorohidrin pada kondisi basa untuk memberikan derivat epoksi selulosa yang memudahkan reaksi dengan dietilentriamina.

Pola spektrum FTIR selulosa bakterial, natrium selulosa, selulosa epiklorohidrin, selulosa-dietilentriamina, dan logam $\mathrm{Pb}$ dan $\mathrm{Cd}$ teradsorpsi pada selulosa-dietilentriamina dapat dilihat pada Gambar 2.

Gambar 2 menunjukkan spektrum
FTIR dari selulosa bakterial, selulosa dalam kondisi basa, epoksi selulosa dan dietilentriamina - selulosa. Bilangan gelombang puncak utama terletak di sekitar $3446 \mathrm{~cm}^{-1}$ yang berasal dari - $\mathrm{OH}$ stretching selulosa. Tapi pada selulosa bakterial-dietilentriamina, puncak menjadi luas karena keberadaan gugus amina $\mathrm{NH}_{2}$. Bilangan gelombang $1029 \mathrm{~cm}^{-1}$ sesuai untuk C-O-C stretching juga diamati pada semua sampel. Peningkatan puncak luas sekitar $1.795 \mathrm{~cm}^{-1}$ diamati yang menegaskan keberadaan - $\mathrm{NH}$ pada senyawa dietilentriamina - selulosa.

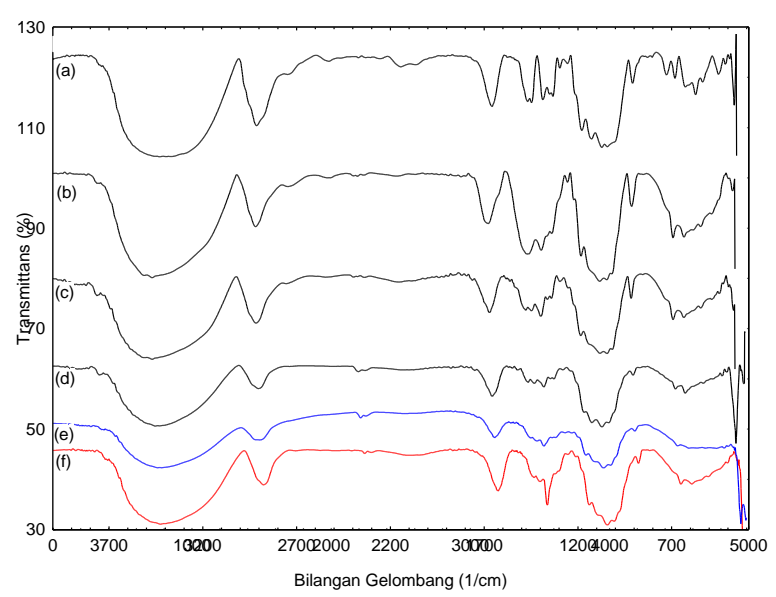

Gambar 2 Spektrum FTIR (a) selulosa bakterial (b). natrium selulosa (c). selulosa epiklorohidrin. (d) selulosa bakterial -dietilentriamina (e) $\mathrm{Pb}$ (II)-selulosa bakterial dietilentriamina. (f) $\mathrm{Cd}(\mathrm{II})$-selulosa bakterial -dietilentriamina.

\section{Konsentrasi Logam Pb(II) dalam Air}

Aplikasi metode gradien difusi pada film tipis (DGT) dengan lapisan pengikat selulosa bakterial-dietilentriamina dan lapisan difusi poliakrilamida dilakukan pada sampel air dari perairan laut Teluk Palu. Sampel air laut Teluk Palu diambil dari empat titik lokasi pada sepanjang 
pesisir perairan laut Teluk Palu. Adapun koordinat geografis masing-masing lokasi adalah:

- Lokasil : LS 0052'40,45” BT $119^{\circ} 50^{\prime} 16,75^{\prime \prime}$

- Lokasi II : LS 0053'00,92” BT $119^{\circ} 50^{\prime} 56,07 "$

- Lokasi III : LS 0052'33,38” BT $119^{\circ} 52^{\prime} 19,35^{\prime \prime}$

- Lokasi IV : LS 0051'32,05” BT $119^{\circ} 52^{\prime} 45,84 "$

Hasil analisis konsentrasi logam $\mathrm{Pb}$ (II) yang terlarut dalam air laut terdeteksi pada kisaran 0,024-0,048 mg/L.

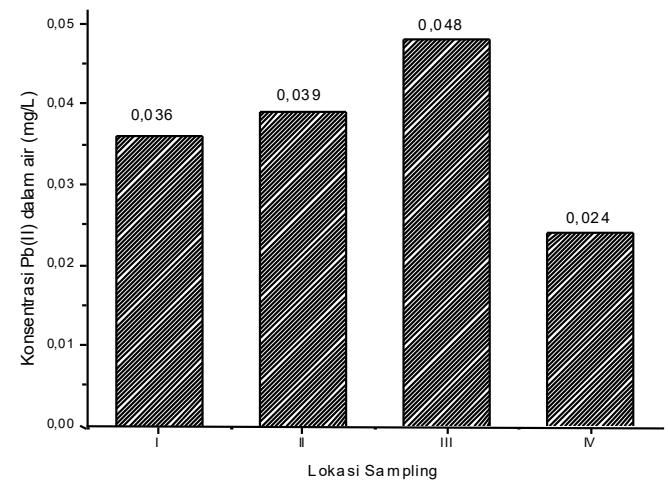

Gambar 3 Rerata Konsentrasi Ion $\mathrm{Pb}$ (II) dalam Air Laut.

\section{Akumulasi Logam $\quad \mathrm{Pb}(\mathrm{II})$ dalam Sedimen}

Rerata konsentrasi logam timbal (II) dalam sedimen tertinggi di peroleh pada lokasi III yaitu $16,043 \mathrm{mg} / \mathrm{L}$ dan terendah diperoleh pada lokasi IV yaitu $7,426 \mathrm{mg} / \mathrm{L}$ seperti terlihat pada Gambar 4.

Hasil analisis regresi parsial antara konsentrasi logam timbal (II) dalam air dengan konsentrasi logam timbal (II) dalam sedimen diperoleh persamaan regresi yaitu: $Y=361,9 X-0,638$, dimana
$\mathrm{Y}=$ konsentrasi logam $\mathrm{Pb}(\mathrm{II})$ dalam sedimen dan $\mathrm{X}=$ konsentrasi logam timbal (II) dalam air dengan koefisien regresi $(R 2)=0,925$. Dengan demikian dapat dinyatakan bahwa konsentrasi logam timbal (II) dalam sedimen ditentukan oleh keberadaan logam timbal (II) dalam air.

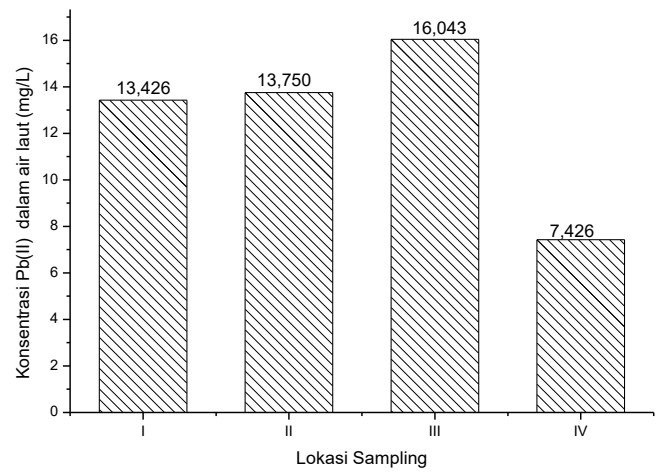

Gambar 4 Rerata Konsentrasi Ion Logam $\mathrm{Pb}$ (II) Dalam Sedimen.

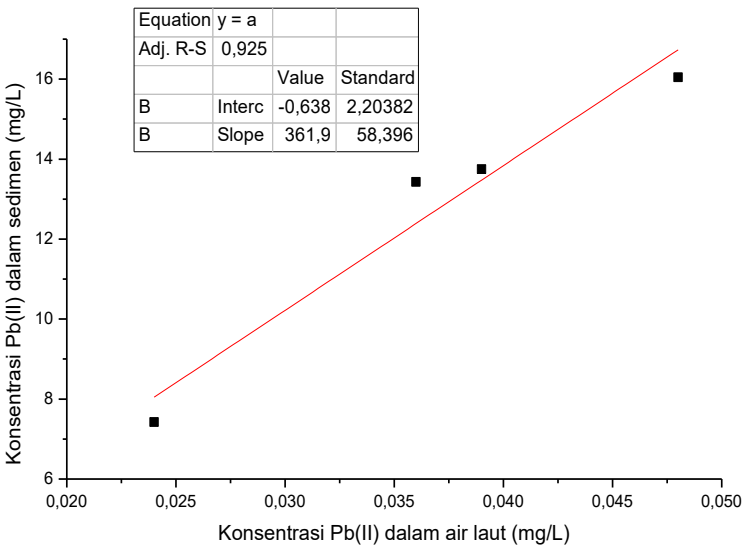

Gambar 5 Hubungan Konsentrasi Ion $\mathrm{Pb}$ (II) dalam Air dan Sedimen.

\section{Konsentrasi Logam Cd(II) dalam Air}

Konsentrasi rerata logam $\mathrm{Cd}(\mathrm{II})$ tertinggi diperoleh pada lokasi III yaitu 0,015 $\mathrm{mg} / \mathrm{L}$ dan konsentrasi terendah diperoleh pada lokasi I yaitu $0,006 \mathrm{mg} / \mathrm{L}$. 


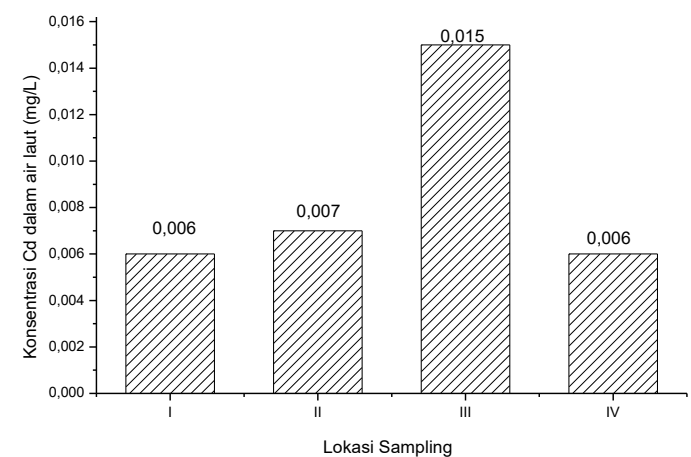

Gambar 6 Rerata Konsentrasi Ion Cd(II) dalam Air Laut.

\section{Konsentrasi Logam Cd(II) Dalam Sedimen.}

Rerata konsentrasi ion $\mathrm{Cd}(\mathrm{II})$ dalam sedimen tertinggi di peroleh pada lokasi III yaitu $0,950 \mathrm{mg} / \mathrm{L}$ dan terendah diperoleh pada lokasi IV yaitu $0,387 \mathrm{mg} / \mathrm{L}$.

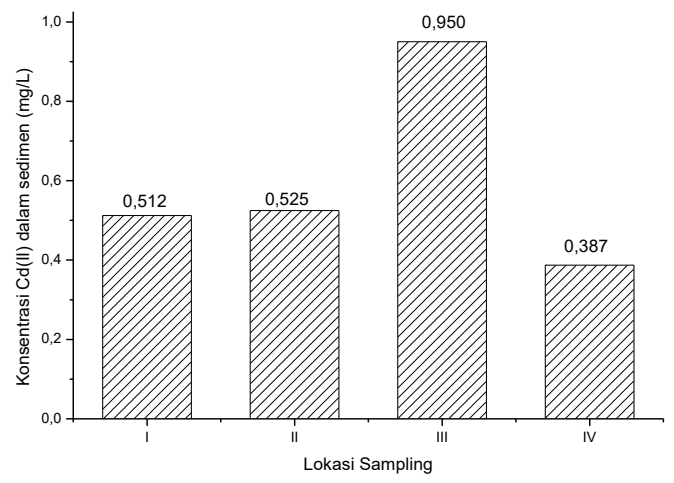

Gambar 7 Rerata Konsentrasi Ion $\mathrm{Cd}(\mathrm{II})$ dalam Sedimen.

Hasil analisis regresi parsial antara konsentrasi logam kadmium (II) dalam air dengan konsentrasi logam kadmium (II) dalam sedimen diperoleh persamaan regresi yaitu: $Y=55,087 X+0,1252$, dimana $Y=$ konsentrasi logam kadmium (II) dalam sedimen dan $X=$ konsentrasi logam kadmium (II) dalam air dengan koefisien regresi $(R 2)=0,9329$. Hasil ini menunjukkan bahwa antara konsentrasi ion logam $\mathrm{Cd}(\mathrm{II})$ dalam air memiliki korelasi yang positif dengan konsentrasi logam $\mathrm{Cd}(\mathrm{II})$ dalam sedimen.

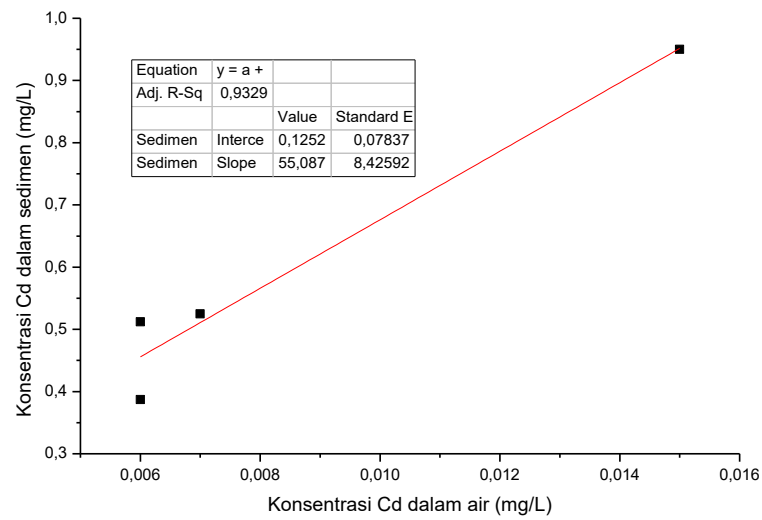

Gambar 8 Hubungan Konsentrasi Ion $\mathrm{Cd}(\mathrm{II})$ dalam Air dan Sedimen.

\section{KESIMPULAN}

Berdasarkan hasil penelitian dapat disimpulkan bahwa konsentrasi $\mathrm{Pb}$ (II) dan $\mathrm{Cd}$ (II) dalam larutan maupun air laut dapat diukur dengan metode DGT menggunakan gel lapisan pengikat logam selulosa - dietilentriamina.

Konsentrasi logam berat terlarut dalam air laut untuk $\mathrm{Pb}$ berkisar antara 0,024 - 0,048 mg/l, sedangkan untuk Cd berkisar antara $(0,006-0,015) \mathrm{mg} / \mathrm{L}$. Konsentrasi $\mathrm{Pb}$ dalam sedimen berkisar $(7,426$ - 16,043) mg/L dan Cd berkisar $(0,387-0,950) \mathrm{mg} / \mathrm{L}$.

\section{DAFTAR PUSTAKA}

Ahmad R., Rajeev K., Haseeb S. 2012. Adsorption of $\mathrm{Cu}^{2+}$ from aqueous solution onto iron oxide coated eggshell powder: Evaluation of equilibrium, isotherms, kinetics, and regeneration capacity. Arabian Journal of Chemistry. 5 353-359.

Chethan P.D., B. Vishalakshi. 2015. Synthesis of ethylenediamine modified chitosan microspheres forremoval of divalent and hexavalent ions. International Journal of Biological 
Macromolecules, 75: 179-185.

Czaja W, Romanovicz D., and Brown R. M. 2004. Structural investigations of microbial cellulose produced in stationary and agitated culture. Cellulose. 11: 403-411.

Dahlqvist R., Zhang, H., Ingri, J. 2002. Performance of the diffusive gradients in thin films technique for measuring $\mathrm{Ca}$ and $\mathrm{Mg}$ in freshwater. Analytica Chimica Acta. 460: 247 256.

Dunn R.J.K., Teasdale, P.R., Warnken, J., Jordan M.A. 2007. Evaluation of the in situ, time-integrated DGT technique by monitoring changes in heavy metal concentrations in estuarine waters. Environmental Pollution. 148: 213 - 220.

Mojsilovic O., McLaren R.G., Condron, L.M. 2011. Modelling arsenic toxicity in wheat: Simultaneous application of diffusive gradients in thin films to arsenic and phosphorus in soil. Environmental Pollution. 159: 29963002.

Morford J., Kalnejaisa L., Martina W., Francoisa R., Karleb I.M. 2003. Sampling marine pore waters for $\mathrm{Mn}, \mathrm{Fe}, \mathrm{U}, \mathrm{Re}$ and Mo: modifications on diffusional equilibration thin film gel probes. Journal of Experimental Marine Biology and Ecology. 285: 85- 103.

Scally S., Davison, W., Zhang, H. 2006. Diffusion coefficients of metals and metal complexes in hydrogels used in diffusive gradients in thin films, Analytica Chimica Acta. 558: 222229.

Shaaban A.F., Fadel D.A., Mahmouda A.A., Elkomy M.A., Elbahy S.M. 2014. Synthesis of a new chelating bearing amidoxime group for adsorption of $\mathrm{Cu}(\mathrm{II}), \mathrm{Ni}(\mathrm{II})$ and $\mathrm{Pb}$ (II) by batch and fixed-bed column methods. Journal of Environmental Chemical Engineering. 2: 632-641. 